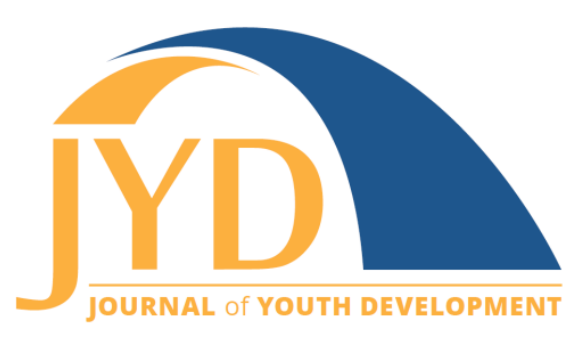

http://jyd.pitt.edu/ | Vol. 16 Issue 2-3 DOI 10.5195/jyd.2021.1023 | ISSN 2325-4017 (online)

\title{
On the Right Path: Youth Development Amidst Colombia's Sociocultural Transition
}

\author{
Holly E. Follmer-Reece \\ Center for Adolescent Resiliency, Texas Tech University \\ holly.follmer@ttu.edu \\ Paulina Velez-Gomez \\ Department of Psychology, Universidad CES \\ pvelezg@ces.edu.co \\ Nadia Semenova Moratto-Vásquez \\ Department of Psychology, Universidad CES \\ nmoratto@ces.edu.co

\section{Sara L. Dodd} \\ Center for Adolescent Resiliency, Texas Tech University \\ sara.dodd@ttu.edu
}

\section{Abstract}

Colombia is amidst a sociocultural transition due to recent political movements towards ending the longstanding internal armed conflict. Development and implementation of youth programs that are responsive to the current societal context can contribute to this transition by investing in younger generations. This study features findings from the exploration phase of a community-based participatory research study to adapt a youth program from the United States for implementation in Colombia. Through focus group interviews, participants representing 4 different microsystems surrounding youth shared perceptions of youth who will be successful in this transitional context. Perceptions coalesced to reveal a process of positive development for use as a framework for responsive and culturally sensitive program adaptations. The emergent process mirrors positive youth development principles and shares similarities with other positive youth development models. The discussion explores considerations for the sociocultural context when designing youth programs for use in Colombia.

Key words: youth program, youth development, Colombia, qualitative research

(cc) EY New articles in this journal are licensed under a Creative Commons Attribution 4.0 License. This journal is published by the University Library System, University of Pittsburgh and is cosponsored by the University of Pittsburgh Press. The Journal of Youth Development is the official peer-reviewed publication of the National Association of Extension 4-H Youth Development Professionals and the National AfterSchool Association. 


\section{Introduction}

Despite being one of the most bio-diverse places in the world, Colombia's global reputation instead is associated with violence. Since the 1960s, Colombia has endured an internal armed conflict between left-wing guerrillas and right-wing paramilitary forces wrestling for political and economic power. The Colombian conflict is responsible for over 230,000 deaths, 4,210 massacres, 25,000 missing persons, and 15,222 events of sexual violence (National Center for Historical Memory, 2020). Violence associated with the conflict has forcibly displaced more than 6.8 million Colombians, generating the world's second largest population of internally displaced persons after Syria (Human Rights Watch, 2017). Despite two decades of substantive progress, Colombia continues to transition between armed truce, disarmament, and reconciliation. The prolonged violence has profoundly impacted the living conditions and well-being of individuals, families, and communities (Carrillo \& Ripoll-Núñez, 2014; Luna, 2019).

The armed conflict has disproportionately affected Colombia's 16.8 million youth. According to UNICEF (2018), children and adolescents are not only victims of anti-personnel mines, unexploded munitions, and improvised explosive devices. Youth also are exposed to recruitment by armed groups, sexual violence associated with the conflict, internal displacement, and deprivation of humanitarian assistance. The psychological, physical, and relational impact on youth with prolonged exposure to trauma and violence can be profound (Barber, 2008; Fernando \& Ferrari, 2013; Garbarino et al., 2015). In recognition of this impact, the Colombian government ratified the Convention on the Rights of the Children in 1991 and has since made significant progress with implementation of public policies that affect the protection and rights of youth.

In 2016, Colombia's Congress approved a revised peace agreement to end the conflict with the Revolutionary Armed Forces of Colombia (FARC), the country's largest rebel group. These negotiations revealed a political and social dichotomy in the country. Some segments of Colombian society see reconciliation as an essential condition for achieving stable and lasting peace; others express strong dissatisfaction for not holding people accountable for their past crimes (Hilton, 2016). Despite opposing views, the prospect of ending the violence has spurred a dynamic sociocultural transition in Colombia.

In this context, it is important consider how Colombian citizens can become transformative agents for new forms of social functioning. Education is a sector that can contribute contemporaneously to the country's reconciliation and rebuilding efforts. Strategic policies and 


\section{Youth in Colombia's Sociocultural Transition}

programs facilitated through schools can positively transform the lives of many Colombian youth by developing and strengthening skills that foster peace and unity in a post-conflict nation.

\section{Challenges to Positive Youth Development}

Theoretical conceptions of positive youth development (PYD) have been framed within the relational developmental systems meta-theoretical perspective (J. V. Lerner et al., 2009). This perspective characterizes human development as involving mutually influential relations between a developing individual and the multiple levels of their changing context. Although different theoretical models of PYD coexist (R. M. Lerner et al., 2011), they all share the premise that young people's strengths are best actualized when leveraged with supportive environments.

The U.S. Agency for International Development ([USAID]; n.d.) and the Interagency Working Group on Youth Programs ([IWGYP]; 2016) provide broad definitions of PYD that encompass core principles that span across models. These principles emphasize youth engagement with family, community, and other social settings such as peer networks, schools, organizations, and government. In the Colombian context, the armed conflict and its inevitable consequences have disrupted these environments.

In their exploration of children's opportunities for agency and participation in citizenship in Colombia, Hart and Mojica (2006) described the armed conflict's impact on thriving environments. Common throughout is the "naturalization" of authoritarianism by which "force determines the social order" (p. 248). Adults exercise control over youth in order to protect the youth, as well as themselves. For example, many families confine themselves and limit children's activities and socialization outside of the home. Teachers and youth workers in schools, programs, and organizations mirror the community's patterns of power and control, lest they or the youth in their care be perceived as subversive. Across environments, democratic processes that provide youth with voice and agency are perceived generally as a threat to all.

Hart and Mojica (2006) identified distrust as another disruptive element to thriving environments. Trusting relationships are necessary for a sense of community and security. Limited opportunities for social interaction, cooperative play, or public space use coupled with the prevalence of gangs, crime, and "spy networks" hinders development of connection to others. Relocation (forced or voluntary) and abduction further exacerbate distrust as families become fragmented, the few social networks youth have are eroded and community outsiders 


\section{Youth in Colombia's Sociocultural Transition}

are shunned. Positive relationships are essential to the positive development of youth (IWGYP, 2016; USAID, 2012). Societal conditions in Colombia during armed-conflict obstruct opportunities to build these relationships.

Emerging efforts towards post-conflict unity and peace in Colombia offer opportunities for new sociocultural functioning. Local, national, and international government and non-governmental organizations (NGOs) have implemented a variety of programs to rebuild the fabric of Colombian society. Implementation of in- and out-of-school programs guided by PYD principles is a promising approach for youth. Research demonstrates that PYD programs in high-income countries (HIC) have positive short- and long-term effects such as reduced behavioral problems, better mental and physical health, and general well-being of youth, their families, and their communities (Benson et al., 2011; Catalano et al., 2002; R. M. Lerner et al., 2005). Considerably less research exists on the efficacy of PYD programs in low- and middle-income countries (LMIC), yet a systematic review of evaluation reports revealed promising evidence of positive effects (Catalano et al., 2019).

\section{Background of Study}

The present study is derived from a larger research project between two universities, one in Colombia and one in the United States. Institutional Review Boards at the authors' respective universities approved the larger research project which aims to adapt and implement an existing leadership development program for youth in Colombia. The United Future Leaders (UFL) program, guided by PYD (R. M. Lerner et al., 2005) and Self-determination Theory (Deci \& Ryan, 2000) empowers youth to impact their communities through service, mentoring and relationship building (Kostina-Ritchey et al., 2015, 2017). Through the promotion of civility, ethics, and leadership, program participants gain a strong foundation for individual and selfawareness which serves as a springboard for servant leadership (Kostina-Ritchey et al., 2015, 2017).

The larger study explored whether the structure and curricula of the U.S. program would be relevant, acceptable, and effective for youth in Colombia. The long-term goal of the project is to help rebuild the civic and social fabric of Colombia by investing directly in youth.

The larger study consisted of three phases. Phase 1 consisted of a needs assessment to gain input from relevant stakeholders on (a) the need for a youth leadership program in this 


\section{Youth in Colombia's Sociocultural Transition}

particular context; (b) the cultural understandings of program core components; (c) the potential differences in values, beliefs, and characteristics between the target population and the population for which the program was originally developed; and (d) the best mechanisms to implement the program.

Phase 2 focused on piloting the program and included three distinct steps. First, results from Phase 1 were used to make curricular adaptations. Second, sample lessons from the adapted curriculum were piloted in two Colombian schools. And third, data from the pilot lessons were used to further adapt the curricula and design training for the adults implementing the program in Colombia. Phase 3 consisted of developing and validating instruments to evaluate the program.

\section{Framework}

The sociocultural transition in post-conflict Colombia affects every individual at every level of society. To better address youth and account for the various levels or systems surrounding them, the larger study was guided by Bronfenbrenner's (1989) ecological-systems approach. This perspective focuses on how interactions between individual and contextual factors shape interpersonal relationship processes, and highlights connections between everyday contexts and larger contextual forces (Updegraff \& Umaña-Taylor, 2010). Researchers employed a community-based participatory research (CBPR) approach. CBPR engages diverse partners in strategies aimed at obtaining multiple perspectives to address community-identified concerns (Israel et al., 2008). Following CBPR principles, the research process included perspectives of all collaborators in all phases of the study (Minkler \& Wallerstein, 2008).

When designing and implementing a program in another country, community members and stakeholders can assist project leaders in increasing cultural fit and acceptance of the program into the community (Stith et al., 2006). Key stakeholder feedback is critical to producing programs that are culturally sensitive, responsive to the local environment and its dynamics, and relevant to the target culture (Castro et al., 2004; Israel et al., 2008; Leff et al., 2010; Nastasi et al., 2000). Furthermore, community involvement in program design promotes ownership and empowerment among stakeholders who are responsible for sustaining the program (Nastasi et al., 2000). 


\section{Youth in Colombia's Sociocultural Transition}

\section{Current Study}

The current study presents an alternative exploration of data collected in Phase 1 of the larger study. While conducting content analysis and directional coding for Phase 1 , the first author detected patterns in the data that were suggestive of an underlying process of development. Discussions about the data with the larger study's research team led to additional analysis of the data. Utilizing an approach that would allow process to emerge, the current study reexamined Phase 1 data to explore Colombian stakeholders' perceptions of youth who will thrive (i.e., manifest positive youth development) in the country's current transitional context. The study sought to understand:

1. How do participants describe youth who will be successful in society?

2. What does this success look like?

3. How can emerging thematic descriptions be integrated to provide a guiding framework for youth programming in urban Colombia?

\section{Method}

The current study centered on uncovering stakeholder perspectives of positive, or ideal, youth development in the context of Colombia's sociocultural transition. Considering the qualitative nature of the data to be examined, coupled with the intent to explain a process generated by those experiencing and influencing the phenomenon under study (Creswell, 2007), grounded theory was deemed to be the appropriate methodology to employ.

\section{Participants}

Participants in the current study were key stakeholders for the youth leadership development program being adapted for implementation in Colombia. Participants were purposively selected based on their representation of different environments surrounding youth and consent to be in the study. The final sample included eight schoolteachers (representing six different academic subjects), six school psychologists (representing grades K-11), five fourth-grade students, and nine parents (of the students who participated in the student focus group). Such a sample selection provided access to perspectives of the phenomenon within a specific context (Smith et al., 2009). All participants were associated with a private school in Medellin, Colombia. 


\section{Youth in Colombia's Sociocultural Transition}

\section{Procedures}

Focus groups served as the method of data collection. Focus groups are in-depth group interviews employing relatively homogenous groups to provide information on topics specified by researchers (Hughes \& DuMont, 1993). For this study, focus groups with community members were utilized to facilitate culturally anchored research by challenging researchers' a priori conceptualizations of the phenomenon and identifying constructs important to a group that are absent from current conceptual frameworks (Hughes \& DuMont, 1993). Focus groups allow researchers to explore the nuances and complexities of participants' attitudes and experiences by emphasizing participants' perspectives and the language they use to articulate those perspectives (Hughes \& DuMont, 1993). In the context of CPBR, focus groups aim to better understand strengths and challenges of the local community (Kieffer et al., 2012).

The second author (a native Colombian with years of experience in the United States and with the program being adapted) facilitated all focus groups. A semi-structured interview protocol guided the discussion of (a) participants' ideas of what it looked like for youth to be successful or "on the right path," (b) their goals and hopes for the future, (c) the challenges faced by youth, and (d) other questions related to their perceptions of the program to be adapted. Additional questions were asked to clarify ideas and as a means to balance the interpersonal dynamics of each group (Greenbaum, 2000).

Focus groups were conducted in school facilities, following the Kieffer et al. (2012) suggestion to hold focus groups in settings familiar to participants to further enhance the participants' engagement in the focus groups. Two research assistants from Universidad CES took field notes throughout each focus group and transcribed recordings of the discussions. Transcripts were translated from Spanish to English by a translator certified in Colombia and then verified by the second and third authors.

\section{Data Analysis}

The first author used open-coding procedures outlined by LaRossa (2005) to analyze transcript data. Starting with line-by-line coding (Charmaz, 2014), indicators were assigned to the raw data using both in-vivo and descriptive codes (Richards \& Morse, 2013). Indicators then were clustered into concepts using a concept-indicator model (LaRossa, 2005). Concepts were then arrayed to form categories, groupings of (a) similar but not identical concepts or (b) dissimilar but allied concepts (LaRossa, 2005). 
Constant comparison (Glaser, 1965) of indicators, concepts, and categories to identify similarities and variances facilitated the open-coding data abstraction. Figures were drafted and reworked throughout the analysis to explore connections and links among concepts and categories (Richards \& Morse, 2013). Credibility (Sandelowski, 1986) of the analysis was ensured by (a) discussion of interpretations between the first and second authors throughout data analysis, (b) peer debriefing (Lincoln \& Guba, 1985) with the third and fourth authors, and (c) frequently checking both the English and Spanish versions of the transcripts to verify interpretations against the original text.

\section{Results}

Nine categories emerged from participants' conceptualizations of youth who will positively influence Colombia's post-conflict society. Consideration of how these categories linked and related to each other yielded three groupings that coincided with the current study's research questions. Five categories worked together to describe what it means to be "on the right path." Three categories depicted what success looks like when youth stay on that path. The final category facilitated the integration of categories to reveal an overall process of youth development. The subsections below, organized in the order of the research questions, present descriptions of each category. Table 1 contains sample quotes for each category.

Table 1. Sample Quotes for Emergent Categories

\begin{tabular}{|l|l|}
\hline \multicolumn{1}{|c|}{ Category } & \multicolumn{1}{c|}{ Quote } \\
\hline Knowing the self & $\begin{array}{c}\text { That she can live everything that comes out of her in any context where she develops } \\
\text {... that she can draw from herself what she has from within and can express it } \\
\text { spontaneously. That she can interact with others without wearing a mask. (Psychologist 3, } \\
\text { Prek-2 }{ }^{\text {nd }} \text { grade, female) }\end{array}$ \\
\hline $\begin{array}{l}\text { Yelf in context } \\
\text { context, to a community, and that not only thinking about an individual good but also about } \\
\text { a common good. (Psychologist 2, Coordinator, female) }\end{array}$ \\
\hline
\end{tabular}


Journal of Youth Development | http://jyd.pitt.edu/ | Vol. 16 Issue 2-3 DOI 10.5195/jyd.2021.1023

Youth in Colombia's Sociocultural Transition

Table 1. (continued)

\begin{tabular}{|c|c|}
\hline Category & Quote \\
\hline Assert & $\begin{array}{l}\text { That's why I said that they mark the line, right? My child has his goal set, right? . . } \\
\text { The friends are saying "here or there" and they have to be able to say, "my line is the one I } \\
\text { follow, no other. "(Parent } 2,4^{\text {th }} \text { grade, male) } \\
\text { Having the ability to, as I said, of not letting themselves be put down by others. } \\
\text { Because a leader is always going to maintain the same position on his decisions. So, others } \\
\text { are going to want to oppose, but he cannot change decision. (Student } 5,4^{\text {th }} \text { grade, male) }\end{array}$ \\
\hline Belonging & $\begin{array}{l}\text { Not only I value the other, but I also feel valued, important, loved, recognized within } \\
\text { that environment to which I belong; feeling that I have empathy, that I am well received. } \\
\text { (Teacher, Spanish, female) }\end{array}$ \\
\hline $\begin{array}{l}\text { Family- } \\
\text { acompañamiento }\end{array}$ & $\begin{array}{l}\text { If he is not prepared, if he does not have the foundations that you give him at home, } \\
\text { then, there are problems. Plus, the problems that we are seeing now with adolescents in } \\
\text { society. There are many issues that must have very good foundations and these } \\
\text { foundations are given by us at home. We set them. As [my] companion says, if we do not } \\
\text { accompany them and it's their friends who set those foundations, they end up destroying } \\
\text { then that castle that we are building for them as people. (Parent } 9,4^{\text {th }} \text { grade, male) }\end{array}$ \\
\hline Self-discipline & $\begin{array}{l}\text { I wish to be like my mom because whenever there are difficulties, she makes the effort } \\
\text { to overcome them. (Student } 4,4^{\text {th }} \text { grade, female) } \\
\text { Responsibility. Commitment. That he is a dedicated person ... a lot of commitment to } \\
\text { what you are going to start to undertake. (Parent } 2,4^{\text {th }} \text { grade, male) }\end{array}$ \\
\hline Service to society & $\begin{array}{l}\text { Service is to take care of the other person and to be there for them. } \\
\text { (Student } 3,4^{\text {th }} \text { grade, male) } \\
\text { Service. Helping the other. Working for the other. Being part of the community, right? } \\
\text { Being a useful part of the community from serving. (Psychologist } 1,3^{\text {rd }-5^{\text {th }} \text { grade, female) }}\end{array}$ \\
\hline $\begin{array}{l}\text { Responsible } \\
\text { happiness }\end{array}$ & $\begin{array}{l}\text { Understanding happiness in relation to others-a responsible happiness with } \\
\text { commitment to themselves and to others. (Teacher, English, male) }\end{array}$ \\
\hline $\begin{array}{l}\text { Social-emotional } \\
\text { competence }\end{array}$ & $\begin{array}{l}\text { He has the capacity to congregate, to dialogue, to resolve conflicts, to understand that } \\
\text { conflicts are inherent to human beings and that this cannot be avoided and that, since they } \\
\text { cannot be avoided, they must be solved in a peaceful way. (Teacher, math, female) }\end{array}$ \\
\hline
\end{tabular}




\section{On the Right Path}

Participants perceived youth "on the right path" as those who find balance between being an individual and being part of a group or larger society. Primary to being an individual was the notion of truly knowing the self. Knowing the self was described as being aware of one's beliefs, values, interests, desires-that is, all the components that make up one's identity and individuality. Of equal importance was being comfortable with and accepting of that self.

At the same time, participants recognized that individuals are part of the context and the two cannot be separated. The self is influenced by the context (i.e., societal norms) and the context is influenced by the self (i.e., decisions made for the self affect others). Self in context is recognition of this symbiotic relationship. Participants, especially the parents, believed that the individual good and common good are one and the same; others around the individual will grow as he or she grows. Thus, youth on the right path factor the social context into their decision making.

Forces exist that can draw youth more toward an individualistic or group orientation. To resist negative social pressures, participants found it important for youth to assert themselves. Knowing the self includes knowing one's limits, and asserting the self is not being afraid to express what those limits are. Being on the right path is having the courage to be different from the group, especially when the group is acting in a manner contrary to the values one holds. Youth should be true to themselves regardless of the context or challenge.

Asserting the self too much, however, can keep one from being a member of the group or community. Being on the outside of the group gives way to devaluing diversity and rejecting the group norms that may govern the lives of others. Participants believed that youth will experience more motivation to act on behalf of those within the various levels of societyfamily, school, community, and other environments-when they feel authentically connected. Thus, a sense of belonging to society is necessary.

Integral to helping youth establish and maintain balance between individual and group orientation is family or a family-like group. Family serves as a gatekeeper determining who, when, where, and how youth interact with the broader societal context which, in turn, affects how much influence society can have on the development of the individual. This gatekeeping is managed through acompañamiento, where parents serve as trusted guides and companions along a child's life-path. Family-acompañamiento was the most prevalent category to emerge 


\section{Youth in Colombia's Sociocultural Transition}

from focus groups, with participants discussing family in $33 \%$ of the transcript pages and acompañamiento in $48 \%$.

\section{What Success Looks Like}

With the establishment and maintenance of balance between being an individual and being part of society, the individual is primed to higher aspirations for the self and for others. Selfdiscipline was the primary outcome identified by participants. Self-discipline encompasses a variety of qualities-hard-work, dedication, perseverance-that speak to a level of commitment to a variety of life's endeavors. Endeavors may be compulsory, such as school, or chosen, such as participation in a sport. Important to participants was the notion that this discipline comes from within an individual rather than being imposed by others.

Self-discipline was seen as the lynchpin to other achievements such as service to society. A disciplined person contributes to the community and larger society by giving the best and strongest parts of the self for the benefit of others. Sharing talents, helping, exercising empathy, and even complying with laws and rules were the means mentioned through which youth can serve. The individual actively contributes to society through service, which reflects both belonging and acceptance of others.

The main goal participants saw for positively developing youth and society is to develop responsible happiness, where happiness is a sense of fulfillment and accomplishment across life contexts. When an individual or group obtains this happiness at the expense of others' happiness, it becomes tainted. Self-disciplined individuals offer their best selves through service; when society receives the best of everyone, then everyone can experience happiness. Creating conditions in which everyone can have this shared experience is thus conceptualized as responsible happiness.

\section{Integration for Guiding Framework}

The use of figures throughout the analysis helped determine the best integration and representation of ideas. Consistently, one category, social-emotional competence, was difficult to place as aspects of it related to each of the other categories. Social-emotional competence is an umbrella term encompassing the various skills and abilities identified by participants, such as autonomy, self-control, communication skills, and interpersonal skills. Participants thought social-emotional competence could direct youth toward the right path, guide them on that 
path, and then lead them toward successful outcomes. Given its connection to each category individually and the interaction of the categories, the researchers concluded that socialemotional competence was both the engine moving the developmental process and the conduit through which parts of the process comingle.

Adult participants expressed concern that the skills and abilities they see as effectively supporting youth in a post-conflict Colombia are not commonly displayed by those who will be guiding the youth. The historical, social, and political context of the country hindered older generations' opportunities to learn, develop, and practice social-emotional competence. Adults or older peers promoting social-emotional competence must be competent themselves and, therefore, social-emotional competence must be co-learned, exercised, and promoted in all of society.

Figure 1 depicts how the nine categories emerging from the current study relate to each other. To the left is social-emotional competence, represented by an arrow. This category is the common thread in the process of positive development of youth who will thrive in Colombia's post-conflict society, influencing all parts and interactions of the development process. At times social-emotional competence may be working in the background but is always at play.

Figure 1. Depiction of Participant Perceptions of Youth Who Will Be Successful in Post-Conflict Colombia

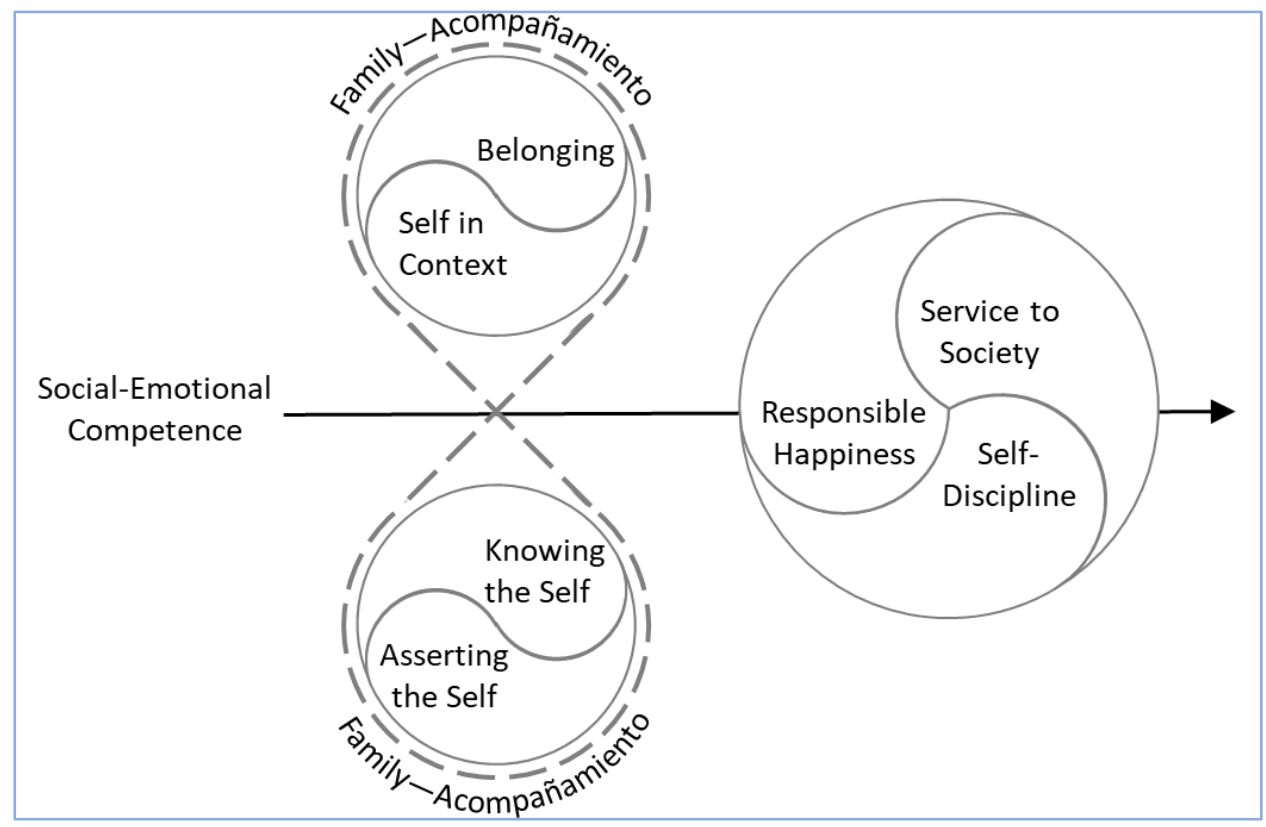


The figure eight in the middle represents the qualities of youth on the right path. Separate circles for the individual and society are aligned to indicate balance. The curved line within each circle is for fluidity as each category ebbs and flows depending upon the situation and need. As the gatekeeper between youth and others, family-acompañamiento is a dotted line to represent both access and boundaries. The semblance of an infinity symbol represents (a) movement as the gatekeepers adjust in response to situations and (b) continuity as families accompany youth throughout development.

The circle on the right depicts the successful outcomes stemming from being on the right path. While one category may stand on its own, two cannot exist without the third; all three are needed to achieve the ultimate positive outcome. The shape of the categories suggest flow from one to the other in a cyclic, self-reinforcing fashion.

\section{Discussion}

Recent efforts to end the long-standing internal armed conflict in Colombia signal a sociocultural shift throughout the country. Conceptualizing, developing, and implementing youth programs that are sensitive to the country's context and goals can propel this transition by investing in younger generations. The current study explored stakeholders' perceptions of youth who will be successful in Colombia's post-conflict society. Inductive analysis and abstraction of focus group data informed adaptations to a U.S. youth program for implementation in Colombia and provided valuable insights for urban youth programming in Colombia.

Participants in the current study advocated for new models of social functioning for younger generations in Colombia. Social-emotional competence was seen as the driving force that would bring sociocultural changes. Youth programming is an accessible environment where socialemotional competence can be learned, practiced, and encouraged and thus be leveraged to promote positive interactions (Roth \& Brooks-Gunn, 2003). Prosocial practices such as this are in stark contrast to Colombia's historical and permeating culture of violence, whereby the use of force establishes social order (Hart \& Mojica, 2006). Youth in Colombia face distorted perceptions of justice and authority (Bello, as cited by Hart \& Mojica, 2006). As tools for 


\section{Youth in Colombia's Sociocultural Transition}

reconstructing Colombia's sociocultural fabric, youth programs should address perceptions of justice, authority, and social order in conjunction with social-emotional competence.

The UFL program exemplifies a well-established and well-accepted programmatic approach to promoting social-emotional competence in youth through experiential learning curricula (Kostina-Ritchey et al., 2015, 2017). In the U.S. context, these skills and abilities do not challenge the sociocultural status quo. In the context of Colombia, perceptions of subversion remain prominent. Youth learning social-emotional competence through a program such as UFL may experience cognitive dissonance as behavioral expectations in the program may compete with those in other social environments. Consideration should be given to using the program as a forum where youth can process cognitive dissonance and respond to it in a manner consistent with sociocultural dynamics.

In addition to teaching youth social-emotional competence (including how to reconcile competing social demands), the adapted program should account for how others in the Colombian community may react to the program or its curricula. Persuasion, education, communication, and negotiation are competencies needed in the Colombian context that may not be familiar to the adults who would lead a UFL-like program. This issue can be an opportunity rather than a hurdle. Consistent with PYD principles of constructively engaging youth within their communities to effect positive change (e.g., IWGYP, 2016; USAID, 2012), program leaders and participants can work together to devise ways to promote acceptance of the sociocultural changes taking place.

Turning the issue of community buy-in into a service activity has the potential to integrate several aspects of PYD for youth such as purpose (Damon, 2008) and agency (e.g., Dawes \& Larson, 2011). Allowing youth to take on responsibility and ownership also addresses key features of successful PYD programs (Eccles \& Gootman, 2002) and shortcomings experienced by other youth programs in Colombia (Hart \& Mojica, 2006).

Adaptations to the original UFL program for the Colombian context also should include expanding adult involvement. Each stakeholder group in the current study was adamant about the cultural parental practice of acompañamiento. This notion of "walking with" youth extends to all domains of the lives of Colombian youth, especially those concerning the development of character, principles, and values. Additionally, participants expressed concern about a possible lack of proficiency in social-emotional competence among adults who are more accustomed to 
pre-reconciliation cultural expectations. Engaging parents, teachers, and even community members can help adults develop this competence and learn ways to support it in youth. An intergenerational program can be more effective than a youth-only program at eliciting positive change, especially in a post-conflict society (Hart \& Mojica, 2006).

Beyond the utility of serving as a framework to inform program design, Colombian stakeholder perceptions of youth development share similarities with other PYD models (see R. M. Lerner et al., 2011). For example, the interplay of the categories knowing the self and self in context is reminiscent of individual $\leftrightarrow$ context relations in the Lerner and Lerner Five Cs Model of PYD (R. M. Lerner et al., 2005). Social-emotional competence is necessary for the manifestation of the five Cs of competence, confidence, character, connection, and caring; service to society is akin to Lerner's sixth C of contribution (R. M. Lerner, 2004). Additionally, the themes of service to society and responsible happiness relate well to Damon's (2004) concept of thriving, in which part of an individual's identity is to pursue goals that benefit the common welfare of the community and larger society.

Many participants in the current study were not familiar with PYD as a theory, process, or framework for youth programs, yet the similarities between their perceptions and other conceptualizations of PYD provides support for considering PYD as a universal philosophy. Despite finding evidence for the universality of PYD principles, "enabling environments" (USAID, n.d.) of Colombian youth will look different and will present challenges for programming efforts. Engaging local communities in the development and implementation of PYD initiatives helps ensure integration of the unique historical, social, political, and cultural contexts of the community (Castro et al., 2004, Israel et al., 2008; Leff et al., 2010; Nastasi et al., 2000).

The extensive period of upheaval and violence experienced by multiple generations of Colombians inevitably influences social functioning, acceptable patterns of behavior, and aspirations for the next generation. Positive development of youth after disarmament and reconciliation must necessarily be different to ensure that post-conflict sociocultural progress is not interrupted or reversed. Additionally, efforts to promote positive development must be contextualized. When influenced by a collective and purposeful pursuit of healing, reconciliation, and growth, both adults and youth in Colombia may aspire to ownership of a repurposed national identity, a renewed commitment to social justice, and personal investment in the future of their country. 
Journal of Youth Development | http://jyd.pitt.edu/ | Vol. 16 Issue 2-3 DOI 10.5195/jyd.2021.1023

Youth in Colombia's Sociocultural Transition

\section{Author Note}

This study was funded in part by internal grant Act: 02.2017.009 from the Research and Innovation Department, Universidad CES.

Correspondence concerning this article should be addressed to Sara L. Dodd, Center for Adolescent Resiliency, Texas Tech University, sara.dodd@ttu.edu.

\section{References}

Barber, B. K. (2008). Adolescents and war: How youth deal with political violence. Oxford University Press.

Benson, P. L., Scales, P. C., Syvertsen, A. K. (2011). The contribution of the developmental assets framework to positive youth development theory and practice. Advances in Child Development and Behavior, 41, 197-230. https://doi.org/10.1016/B978-0-12-386492-5.00008-7

Bronfenbrenner, U. (1989). Ecological systems theory. Annals of Child Development, 6, 185-246.

Carrillo, S., \& Ripoll-Núñez, K. (2014). Family policies in Colombia: A focus on policies for vulnerable families. In M. Robila (Ed.), Handbook of family policies across the globe (pp. 425-444). Springer.

Castro, F.G., Barrera, M., \& Martinez, C. (2004). The cultural adaptation of prevention interventions: Resolving the tensions between fidelity and fit. Prevention Science, 5(1), 41-45.

Catalano, R. F., Berglund, M. L., Ryan, J. A. M., Lonczak, H. S., \& Hawkins, J. D. (2002). Positive youth development in the United States: Research findings on evaluations of positive youth development programs. Prevention \& Treatment, 5(1), Article 15. https://doi.org/10.1037/1522$\underline{3736.5 .1 .515 a}$

Catalano, R. F., Skinner, M. L., Alvarado, G., Kapungu, C., Reavley, N., Patton, G. C., Jessee, C., Plaut, D., Moss, C., Bennett, K., Sawyer, S. M., Sebany, M., Sexton, M., Olenik, C., \& Petroni, S. (2019). Positive youth development programs in low- and middle-income countries: A conceptual framework and systematic review of efficacy. Journal of Adolescent Health, 65, 15-31.

\section{https://doi.org/10.1016/i.jadohealth.2019.01.024}

Charmaz, K. (2014). Constructing grounded theory ( $2^{\text {nd }}$ ed.). Sage.

Creswell, J. W. (2007). Qualitative inquiry \& research design: Choosing among five approaches (2 ${ }^{\text {nd }}$ ed.). Sage.

Damon, W. (2004). What is positive youth development? Annals of the American Academy of Political and Social Science, 591(1), 13-24. https://doi.org/10.1177/0002716203260092

Damon, W. (2008). The path to purpose: Helping our children find their calling in life. Free Press, Simon \& Schuster. 
Journal of Youth Development | http://jyd.pitt.edu/ | Vol. 16 Issue 2-3 DOI 10.5195/jyd.2021.1023

Youth in Colombia's Sociocultural Transition

Dawes, N.P., \& Larson, R. (2011). How youth get engaged: Grounded-theory research on motivational development in organized youth programs. Developmental Psychology, 4Х1), 259- 269. https://doi.org/10.1037/a0020729

Deci, E. L., \& Ryan, R. M. (2000). The "what" and "why" of goal pursuits: Human needs and the selfdetermination of behavior. Psychological Inquiry, 11, 227-268. https://doi.org/10.1207/S15327965PLI1104 01

Eccles, J. S., \& Gootman, J. A. (2002). Community programs to promote youth development. National Academy Press.

Fernando, C., \& Ferrari, M. (Eds.). (2013). Handbook of resilience in children of war. Springer.

Garbarino, J., Governale, A., Henry, P., \& Nesi, D. (2015). Children and terrorism. Social Policy Report, 29(2), 1-30. https://doi.org/10.1002/j.2379-3988.2015.tb00083

Glaser, B. G. (1965). The constant comparative method of qualitative analysis. Social Problems, 12(4), 436-445. https://doi.org/10.2307/798843

Greenbaum, T. L. (2000). Moderating focus groups: A practical guide for group facilitation. Sage.

Hart, R. A., \& Mojica, R. (2006). Building citizenship in the face of violence: Opportunities for the agency and participation of children in Colombia. In C. Daiute, A. Beykont, C. Higson-Smith, \& L. Nucci (Eds.), International perspectives on youth conflict and development (pp. 245-268). Oxford University Press.

Hilton, I. (2016, October 3). Why Colombians voted against peace with the Farc. The Guardian. https://www.theguardian.com/commentisfree/2016/oct/03/why-colombians-voted-against-peacefarc-president-santos-better-deal

Hughes, D. L., \& DuMont, K. (1993). Using focus groups to facilitate culturally anchored research. American Journal of Community Psychology, 21, 775-806. https://doi.org/10.1007/BF00942247

Human Rights Watch. (2017). World report: Our annual review of human rights around the globe. https://www.hrw.org/world-report/2017/country-chapters/colombia

Interagency Working Group on Youth Programs. (2016). Pathways for youth: Strategic plan for federal collaboration. https://youth.gov/sites/default/files/IWGYP-Pathways for Youth.pdf

Israel, B. A., Schulz, A. J., Parker, E. A., Becker, A. B., Allen, A. J., \& Guzman, J. R. (2008). Critical issues in developing and following community based participatory research principles. In M. Minkler \& N. Wallerstein (Eds.), Community-based participatory research for health (pp. 53-76). Jossey-Bass.

Kieffer, E. C., Salabarría-Peña, Y., Odoms-Young, A. M., Willis, S. K., Palmisano, G., \& Guzman, R. (2012). The application of focus group methodologies to CBPR. In B. A. Israel, E. Eng, A. J. Schulz, \& E. Parker (Eds.), Methods for community-based participatory research for health (pp. 249-276). Jossey-Bass. 
Kostina-Ritchey, E., Follmer-Reece, H., Dodd, S., Sherman, K., \& Gonzales, G. (2015). United Future Leaders: A case of the use of technology in youth programming and hidden curriculum. In $\mathrm{S}$. Blair, P. Claster \& S. Claster (Eds.), Sociological studies of children and youth: Vol 19. Technology and youth: Growing up in a digital world (pp. 439-461). Emerald.

Kostina-Ritchey, E., Velez-Gomez, P., \& Dodd, S. L. (2017). Student assets and commitment to learning in an afterschool leadership development program: Looking beyond the myths. Middle Grades Research Journal, 11(2), 49-61.

LaRossa, R. (2005). Grounded theory methods and qualitative family research. Journal of Marriage and Family, 67, 837-857. https://doi.org/10.1111/j.1741-3737.2005.00179.x

Leff, S. S., Thomas, D. E., Vaughn, N. A., Thomas, N. A., MacEvoy, J. P., Freedman, M. A., Abdul-Kabir, S., Woodlock, J., Guerra, T., Bradshaw, A. S., Woodburn, E. M., Myers, R., \& Fein, J. A. (2010). Using community-based participatory research to develop the PARTNERS youth violence prevention program. Progress in Community Health Partnerships: Research, Education, and Action, 4(3), 207-2016. https://doi.org/10.1353/cpr.2010.0005

Lerner, R. M. (2004). Liberty: Thriving and civic engagement among America's youth. Sage.

Lerner, J. V., Phelps, E., Forman, Y., \& Bowers, E. P. (2009). Positive youth development. In R. M. Lerner \& L. Steinberg (Eds.) Handbook of adolescent psychology: Vol 1. Individual bases of adolescent development ( $3^{\text {rd }}$ ed., pp. 524-558). Wiley.

Lerner, R. M., Lerner, J. V., Almerigi, J. B., Theokas, C., Phelps, E., Gestsdottir, S., Naudeau, S. Jelicic, H., Alberts, A., Ma, L., Smith, L. M., Smith, L. M. Bobek, D. L., Richman-Raphael, D., Simpson, I., Christiansen, E. D., \& von Eye, A. (2005). Positive youth development, participation in community youth development programs, and community contributions of fifth-grade adolescents: Findings from the first wave of the 4-H study of positive youth development. Journal of Early Adolescence, 25(1), 7-71. https://doi.org/10.1177/0272431604272461

Lerner, R., M., Lerner, J. V., Lewin-Bizan, S., Powers, E. P., Boyd, M. J., Mueller, M. K., Schmid, K. L., \& Napolitano, C. M. (2011). Positive youth development: Processes, programs, and problematics. Journal of Youth Development, 6(3), 38-62.

Lincoln, Y., \& Guba, E. (1985). Naturalistic inquiry. Sage.

Luna, L. (2019). Colombian violent conflict: A historical perspective. International Journal on World Peace, 36(4), 53-83.

Minkler, M., \& Wallerstein, N. (Eds.). (2008). Community-based participatory research for health: From process to outcomes. Jossey-Bass.

Nastasi, B. K., Varjas, K., Schensul, S. L., Silva, K. T., Schensul., J. J., \& Ratnayake, P. (2000). The participatory intervention model: A framework for conceptualizing and promoting intervention acceptability. School Psychology Quarterly, 15(2), 207-232. https://doi.org/10.1037/h0088785 
Journal of Youth Development | http://jyd.pitt.edu/ | Vol. 16 Issue 2-3 DOI 10.5195/jyd.2021.1023

Youth in Colombia's Sociocultural Transition

National Center for Historical Memory. (2020). Estadísticas del conflicto armado en Colombia.

http://www.centrodememoriahistorica.gov.co/micrositios/informeGeneral/estadisticas.html

Richards, L., \& Morse, J. M. (2002). Readme first: A user's guide to qualitative methods ( ${ }^{\text {rd }}$ ed.). Sage.

Roth, J. L., \& Brooks-Gunn, J. (2003). What is a youth development program? Answers from research and practice. Applied Developmental Science, 72 , 94-111.

https://doi.org/10.1207/S1532480XADS0702 6

Sandelowski, M. (1986). The problem of rigor in qualitative research. Advances in Nursing Science, 8, 2737. https://doi.org/10.1097/00012272-198604000-00005

Smith, J.A., Flowers, P., \& Larkin, M. (2009). Interpretive phenomenological analysis: Theory, method, and research. Sage.

Stith, S., Pruitt, I., Dees, J., Fronce, M., Green, N., Som, A., \& Linkh, D. (2006). Implementing community-based prevention programming: A review of the literature. Journal of Primary Prevention, 276), 599-617. https://doi.org/10.1007/s10935-006-0062-8

UNICEF. (2018). Para cada niño, todos los derechos. https://www.unicef.org/media/55871/file/Informe\%20Anual\%20de\%20UNICEF\%202018.pdf

U.S. Agency for International Development. (2012). USAID youth in development policy: Realizing the demographic opportunity. https://www.usaid.gov/sites/default/files/documents/1870/Youth in Development Policy 0.pdf

U.S. Agency for International Development. (n.d.). Youth Power: Promoting positive youth development. https://www.youthpower.org/positive-youth-development

Updegraff, K. A., \& Umaña-Taylor, A. J. (2010). Structure and process in Mexican-origin families and their implication for youth development. In N. S Landale, S. McHale, \& A. Booth (Eds.), Growing up Hispanic: Health and development of children of immigrants (pp. 97-143). The Urban Institute Press. 